\title{
GIRI LOJI DESA DLINGO: SEBUAH STUDI FENOMENOLOGI ATAS KONSEP PEMBANGUNAN DESA*
}

\author{
Hafiez Sofyani \\ Universitas Muhammadiyah Yogyakarta, Jl. Lingkar Selatan, Tamantirto, \\ Kasihan, Bantul, Daerah Istimewa Yogyakarta \\ (hafiez.sofyani@umy.ac.id)
}

\begin{abstract}
ABSTRAK
Direvisinya Undang-Undang Desa No. 6/2014 menjadi harapan banyak warga desa, khususnya untuk menjadi institusi mandiri dalam mengelola sumber daya milik desa. Namun banyak kalangan yang meragukan sumber daya manusia desa mampu untuk memenuhi amanat undang-undang tersebut. Menariknya, dari sekian banyak permasalahan implementasi UU Desa, juga tidak sedikit desa yang berhasil berkat otonomi yang diberikan peraturan baru tersebut. Dalam studi fenomenologi ini, peneliti mencoba menggali keberhasilan Desa Dlingo, Bantul, Daerah Isitimea Yogyakarta yang dulunya menjadi desa terpuruk dan kini menjadi desa percontohan dalam pengelolaan dan tata kelola desa. Gagasan ideologi dan pandangan Lurah Dlingo tentang pembangunan desa kemudian dapat digali oleh peneliti. Dalam Pembangunan organisasi, termasuk pemerintahan desa, memahami konsep modern seperti New Public Management atau Good government Governance saja tidak cukup. Bagi beliau tidak hanya soal sistem dan strukturyang perlu dibenahi, tetapi upaya membangikitkan jiwa dan semangat masayarakat desa untuk berdikari (berdiri di atas kaki sendiri) dan saling bergotong-royong adalah yang paling fundamental. Beliau menambahkan, membangun desa adalah membangkitkan kesadaran dan semangat warga desa bahwa mereka ada untuk "benar-benar ada" di tanahnya sendiri, bukan menjadi obyek pembangunan, yang kadang tidak mampu menghadirkan keadilan.
\end{abstract}

Kata kunci: Undang-Undang Desa; Pengelolaan; Tata Kelola; Fenomenologis; Berdikari

\begin{abstract}
The revision of Village Govenment Law no. 6/2014 is the hope of many villagers, especially to become an independent institution in managing the village's resources. However, many people doubting that human resources in village are able to fulfill the mandate of the law. Interestingly, from the many problems of implementation of the Village Law, there are several villages are successful due to the autonomy given. In this phenomenology study, researcher tried to explore the success of Dlingo Village, Bantul, Daerah Isitimea Yogyakarta which used to be a slumped village where now become role model village in village management and governance. The idea of Dlingo Village ideology and views on village development
\end{abstract}

* Penelitian ini didanai dari Hibah Penelitian LP3M UMY 
can then be explored by researcher. In the development of organizations, including village administrations, understanding modern concepts such as New Public Management or Good Governance is not enough. For him it is not just about systems and structures that need to be addressed, but the effort to inculcate the spirit of the village community to be "berdikari" (autonomous) is the most fundamental. He explains that build the village is raising awareness and spirit of the villagers to understand that they exist have to be "really exist" in their own land, rather than being the object of development, which sometimes could not bring justice.

Keywords: Village Law; Management; Governance; Phenomenological; Autonomous

\section{PENDAHULUAN}

Era baru tata kelola Desa di Indonesia mulai hadir sejak diterbitkannya UU No. 6 tahun 2014 tentang desa, yang dalam penjelasannya menempatkan desa sebagai daerah otonom. Artinya, dengan amanat yang ada pada UU tersebut, desa mempunyai hak untuk mengatur dan mengurus urusan pemerintahan, kepentingan masyarakat setempat berdasarkan prakarsa masyarakat, hak asal usul, dan atau hak tradisional yang diakui dan dihormati dalam sistem pemerintahan Negara Kesatuan Republik Indonesia.

Konsekuensi praktis dari hadirnya UU Desa ini adalah Pemerintah Desa (Selanjutnya disebut Pemdes) yang memenuhi persyaratan tertentu berhak menerima sejumlah uang sekitar satu milyar rupiah yang ditransfer dari dana Pemerintah Pusat
(Pempus). Faktanya, tidak semua pihak menyikapi kebijakan ini secara positif. Banyak pihak yang menilai bahwa kebijakan ini bakal menjadi lahan baru praktik korupsi dan sumber inefisiensi di level Desa. Untuk itu, maka penting bahwa di level Desa sekalipun perlu diberlakukan adanya sistem pengelolaan organisasi yang baik yang dikenal dengan istilah good governance (Bastian 2006; Mahsun et al. 2007; Jones dan Pendlebury 2010; Ulum dan Sofyani 2016). Usulan agar diselenggarakannya praktik good governance bertujuan untuk mengawasi dan menjamin agar dana desa yang nilainya cukup besar dapat dikelola dengan baik dan mampu mendatangkan nilai tambah (added value) dalam pembangunan desa secara khususnya dan Negara Indonesia secara umumnya. 
Jika melihat kondisi demografi di desa, terkait aspek derajad pendidikan misalnya, jika kemudian dibenturkan dengan tuntutan implementasi praktik good governance di level Desa, maka sudah barang tentu banyak yang minali hal itu sulit dilakukan. Good governance secara konsep menuntut banyak aspek yang pemenuhannya menuntut skill dan kompetensi yang mupuni. Jika mengamati berita-berita di media massa, maka banyak dikabarkan praktik korupsi kian merebak pasca lahirnya UU Desa ini. Hal ini tentu semakin menguatkan bahwa desa memang belum cukup mampu untuk maju dengan segala keterbatasan dari aparatur desa itu sendiri. Namun menariknya, tidak semua desa memiliki prestasi yang buruk dalam pengelolaannya. Lihat saja Dlingo, Puntuk, atau Beberapa desa di Bali. Aparaturnya ternyata mampu mengelola desa-desa mereka menjadi desa yang berkinerja baik dan menciptakan rasa puas bagi masayarakatnya .

Satu yang paling menyita perhatian peneliti adalah Desa Dlingo. Dari wawancara dengan beberapa warga, desa ini adalah salah satu desa yang tadinya tertinggal. Desa ini berada di ujung tenggara Kabupaten Bantul dan berbatasan langsung dengan Kabupaten Gunung Kidul.
Tanahnya tidak cocok untuk pertanian dan perkebunan. Lurah sebelunya masuk penjara karena korupsi Dana Alokasi Umum untuk desa . Namun, dalam kurun waktu tiga tahun (sejak 2013) dan khususnya sejak ada kebijakan baru tentang UU Desa, desa ini menjadi satu dari sedikit desa percontohan di Indonesia dalam hal pengelolaan (management) dan tata kelola (good governance). Hal inilah yang menjadikan peneliti begitu tertarik untuk menggali apa yang sebenarnya terjadi pada desa ini. Pada bservasi awal, peneliti mencoba untuk menanyai beberapa warga kenapa Dlingo kini sangat jauh berbeda?. Semua warga (empat orang dari dusun yang berbeda) yang peneliti tanyai sepakat menjawab yang intinya adalah hal ini karena kita memiliki Lurah yang Baik, Kreatif, Inovatif, Semangat, dan dapat dipercaya. Berangkat dari permasalahan yang dipaparkan di atas, maka peneliti tertarik untuk menggali bagaimana pandangan dan ideologi Lurah Desa Dlingo dalam memaknai pengelolaan (management) dan tata kelola (good governance) di desanya.

Sampai saat ini, studi terkait praktik good governance di desa kebanyakan dilihat dari sisi kepatuhan terhadap Undang-Undang yang berlaku (Subroto 2009; Lestari 
et al. 2014; Suryaningrum 2016; Wida et al. 2017) dan faktor-faktor yang mempengaruhi pengelolaan dana desa (Munti dan Fahlevi 2017). Padalah jika dilihat secara hakiki, pengelolaan dan tata kelola adalah suatu alat atau instrumen guna mencapai tujuan utama, yakni sila ke-5 dari pancasila, yakni keadilan sosial bagi seluruh rakyat Indonesia. Artinya, praktik dari pengelolaan dan tata kelola dalam pembangunan desa tentu dijalankan dengan adalanya pandangan, ideologi, dan pemaknaan dari pelakunya. Orientasi sila ke-5 tadi hanya akan dapat diraih ketika instrumen yang digunakan difaami dan dijalankan secara tepat dan cermat. Oleh sebab itulah, penggalian makna ini penting dilakukan dan peneliti menilai penggunaan pendekatan fenomenologi menjadi lebih tepat untuk digunakan.

\section{TELAAH LITERATUR DAN \\ PERUMUSAN HIPOTESIS}

Undang-Undang Desa

Undang-Udang No 6 tahun 2014 tentang Desa (dibaca: UndangUndang Desa) berisi peraturan yang mengatur beberapa poin tentang desa, yakni: Definisi Desa, Pemerintahan Desa, Pemerintah Desa, badan Permusyawaratan Desa, Dewan Perwakilan Desa, Badan Usaha Milik Desa (BUMDes),
Keuangan Desa, dan aspek rinci lainnya yang jika dianalogikan memiliki pola yang sama dengan konsep pemerintahan di level pemerintah pusat dan pemerintah daerah. UU inilah yang menjelaskan bahwa desa memiliki posisi sebagai daerah otonom yang memiliki hak untuk mengelola dirinya secara mandiri.

Sedangkan otonomi UndangUndang Nomor 23 Tahun 2014 tentang Otonomi Daerah, didefiniskan sebagai hak, wewenang dan kewajiban daerah otonom untuk mengatur dan mengurus sendiri urusan, pemerintahan dan kepentingan masyarakat setempat dalam sistem Negara Kesatuan Republik Indonesia. Pelaksanaan otonomi daerah didasarkan atas pertimbangan bahwa daerah lebih memiliki cukup informasi dan mengetahui kebutuhan masyarakat di daerahnya secara lebih mendalam. Terbitnya UU No. 6 tahun 2014 atau yang sering disebut dengan UndangUndang Desa diharapkan menjadi instrumen pendoronglahirnya kemandirian desa dalam menopang perekonomian Negara Indonesia. Logika berpikirnya adalah, jika seluruh Desa dapat mandiri, swadaya dan swasembada, maka Negara Indonesiapun akan mandiri, 
Swadaya, swasembada, sejahtera, makmur dan sentosa.

Pengelolaan dan Tata Kelola di Desa

$$
\text { Pebangunan desa yang }
$$

diistilahkan peneliti pada penelitian ini adalah proses pengelolaan dan praktik tata kelola dari Pemerintah Desa. Pengelolaan (management) secara sederhana diartikan sebagai proses dalam membuat suatu perencanaan, pengorganisisasian, pengendalian serta memimpin berbagai usaha dari anggota institusi dan juga memanfaatkan sumber daya yang dimiliki untuk mencapai tujuan yang telah dirumuskan (Handoko 2015). Adapun tata kelola (good governance) adalah suatu penyelenggaraan institusi (termasuk desa) yang mengarah kepada tujuan yang baik melalui perumusan kebijakan yang berhubungan dengan masalah-masalah sosial dan sistem nilai dalam operasi organisasi, yang berlaku bagi semua orang di bawah sistem demokrasi (Brinkerhoff dan Brinkerhoff 2011). United Nations Development Programme (UNDP) mendefinisikan sebagai "the exercise of political, economic, and administrative authority to manage a nation's affair at all levels". Menurut definisi UNDP ini, good governance mempunyai tiga kaki (Ulum dan Sofyani, 2016), yaitu: (1) Economic governance; meliputi proses-proses pembuatan keputusan (decision making processes) yang memfasilitasi aktivitas ekonomi di dalam negeri dan interaksi diantara penyelenggara ekonomi. Economic governance mempunyai implikasi terhadap equity, proverty, dan quality of life; (2) Political governance adalah prosesproses pembuatan keputusan untuk formulasi kebijakan; dan (3) Administrative governance adalah sistem implementasi proses kebijakan. Berdasarkan definisi good governance yang diajukan oleh UNDP, diajukan sembilan (9) unsur sebagai karakteristik good governance yang saling memperkuat dan tidak dapat berdiri sendiri (Ulum dan Sofyani 2016). Sembilan karakter tersebut meliputi: participation, rule of law, transparancy, responsiveness, consensus orientation, equity, effectiveness and efficiency, accountability, strategic vision.

Secara spesifik, meskipun desa merupakan entitas yang dipandang cukup kecil, namun dengan nomengklatur pada UU No 6 tahun 2014 tentang Desa yang menempatkan desa sebagai entitas otonom, yakni memiliki kemandirian mengelola dirinya dan berhak memperoleh alokasi dana desa dari pemerintah pusat. Dengan demikian maka praktik good governance sudah 
semestinya menjadi keharusan untuk di jalankan di level desa sekalipun. Menurut (Bastian 2006) azas-azas penegolaan desa, khususnya dalalm aspek keuangan, harus mengedepankan transparansi, akuntablitas, partisipatif, serta sesuai dengan tata tertib peraturan disiplin anggaran. Azas-azas yang dipaparkan tersebut sesungguhnya dalah unsurunsur yang ada dalam konsep good governance yang harus dijalankan dalam seluruh aktivitas desa.

Dari amanat UU Desa dan otonomi daerah, maka pembangunan desa harus senantiasa mendapat perhatian dan dukungan dari berbagai kalangan, tidak terkecuali akademisi. Karenanya, adanya suatu dose yang berhasil untuk mencapai kemandirian sudah selayaknya dapat dijadikan role model bagi desa-desa lain, terlepas dari cocok tidaknya konsep pembanugnan dari desa yang berhasil tersebut dengan desa lain di Indonesia, khususnya karena aspek karakteristik yang berbeda. Konsep pembangunan ini tidak lepas dari pengelolaan (management) dan praktik tata kelola (governance) yang dijalankan. Oleh karena itu, penelitian ini akan menggali aspek pemahaman pemimpin desa percontohan, yakni Lurah Desa Dlingo dalam mengelola dan mengawal praktik tata kelola di desanya.

\section{METODE}

Jenis Penelitian

Jenis penelitian ini adalah penelitian kualitatif dengan pendekatan fenomenologi transedental. Fenomenologi merupakan ilmu (logos) yang mempelajari tentang hal-hal yang tampak. Menurut Muhadjir (2000:116) metode fenomenologi mengakui adanya kebenaran empiris etik yang memerlukan akal budi untuk melacak dan menjelaskan serta berargumentasi. Akal budi disini mengandung makna bahwa kita perlu menggunakan kriteria lebih tinggi lagi dari sekedar truth or false. Dalam penelitian fenomenologi peneliti dituntut untuk mampu mendiskripsikan fenomena yang terjadi sesuai dengan realitas di lapangan (Mamulati et al. 2016). Moustakas (1994) menjelaskan fenomenologi merupakan diskripsi pengalaman-pengalaman. Artinya, untuk menggambarkan seakurat mungkin sebuah fenomena, sekaligus tetap menjaga keadaan sebenarnya seperti yang nampak pada diri informan. Sementara itu, suatu fenomena yang nampak mengandung unsur sosial dan psikologis (Welman dan Kluger, 1999). 
Salah satu ciri fenomenologi trensedental yang dikembangkan Husserl adalah adanya epoche atau bracketing, di mana peneliti harus menyisihkan semua bentuk prakonsep atas fenomena yang diteliti untuk memperoleh gambaran murni (fresh perspective) dari subjek penelitian (Creswell, 2007:59). Proses ini yang disebut sebagai reduksi fenomenologis. Reduksi tahap selanjutnya adalah reduksi eidetic yang ditujukan untuk menemukan eidos atau hakekat atau makna yang tersembunyi dari fenomena yang diamati (Bertens, 1990). Dalam bahasa yang lain, melalui reduksi eidetic maka deskripsi tekstural (textural description) yang merupakan pengalaman informan, dan deskripsi struktural (structural description) yang menjelaskan tentang konteks penelitian dapat dihasilkan. Pada tahap akhir dilakukan reduksi transendental yang merupakan tahapan kunci dalam fenomenologi transendental Husserl. Tujuannya adalah untuk menemukan hakekat atau makna yang sesungguhnya, murni dan utuh. Prosesnya dilakukan dengan seksama, iterative, dan intuitive. Inilah puncak dari seluruh proses dalam fenomenologi transendental Husserl, yang menurut Creswell disebut sebagai "esensi" (the essence) dari hakikat atau makna pengalaman yang sesungguhnya (Creswell, 2007:60).

\section{Informan}

Informan utama dari riset ini adalah pemerintah Desa, yakni Lurah Desa (Kepala Desa) Dlingo Bapak Bahrun Wardoyo. Namun, untuk dapat menguji validitas informasi dari informan utama, peneliti melibatkan informan pendukung yakni Bagian Pembangunan Sarana dan Prasarana (Sarpras), Bapak Bravo, dan kepala dusun (Kadus) dari Dusun Pakis 1 (satu) Bapak Turijan. Dengan adanya informan pendukung ini, maka akan menghindari terjadinya bias normatif pada hasil penelitian, yakni simpulan penelitian yang hanya berdasar pada satu sisi perspektif informan (Creswell 2012).

\section{Teknik Pemerolehan dan Analisis Data}

Teknik analis data menggunakan pendekatan kualitatif. Untuk teknik wawancara yang dipakai adalah wawancara semi-terstruktur dan terbuka, sambil merekamnya dengan audio recorder, lalu mentranskripnya (Creswell 2012). Analisis data dilakukan dengan pendekatan fenomenologis transedental dimana ada lima kunci pokok yang akan digali oleh peneliti, yakni: noema, noesis, epoeche, intentional analysis, dan eidetic reduction (Kamayanti 
2016).Bagian ini memuat tentang rancangan atau desain penelitian, sasaran penelitian (populasi, sampel, informan atau subjek penelitian), teknik pengembangan instrumen dan metode pengumpulan data, pengukuran dan pendefinisian variabel serta teknik analisis data.

\section{HASIL DAN PEMBAHASAN}

Profil Desa Dlingo

Dlingo berasal dari kata Delengo (lihatlah) hal ini terjadi disaat $\mathrm{Ki}$ ageng Perwito Sidiq mengungkap adanya tumurunnya Ratu Kencono di sebuah bukit Gunung Pasar melalui sebuah Bokor Kencono di Desa Krendetan, Delanggu. Hal ini didasari lelaku ki Ageng Giring III untuk meraih kamulyan dengan menggiring wahyu keprabon dari Majapahit (malang). Desa Dlingo yang pada mulanya merupakan daerah inclave Imogiri yang menginduk ke kasunanan Surakarta. Menurut Undang-undang Darurat nomor 5 tahun 1957 daerah enclave Imogiri (Surakarta) dan Kotagede (Surakarta) telah dimasukkan kedalam wilayah Daerah Istimewa Yogyakarta. Berdasarkan Surat Keputusan DPR DIY Nomor 18/K/DPR/1955 dan dituangkan dalam PERDA DIY Nomor 1 tahun 1958 tentang Perubahan Batas - batas dan nama kapanewonkapanewon Imogiri, Gondowulung dan Kotagede dalam Kabupaten Bantul. Dalam rangka menambah kelancaran dan efisiensi pemerintahan Lima kapanewon (Imogiri (ska), Imogiri (Yk), Kotagede (ska), Kotagede (yk), Gondowulung tersebut dijadikan empat kapanewon yakni Imogiri, Dlingo, Banguntapan, Pleret.

Kapanewon Dlingo terdiri dari 6 Desa yakni Dlingo, mangunan, Temuwuh, Muntuk (Imogiri ska) dan Terong, Jatimulyo (kotagede ska). Didalam mengadakan perubahan batas kapanewon-kapanewon tersebut batas-batas desa tidak terjadi perubahan, dan ditentukan Ibu kota Kapanewon/kecamatan untuk perkembangan daerah dikemudian hari dalam lapangan pemerintah, ekonomi, social dan lain sebagainya. Biarpun tempat Ibu Kota telah ditentukan dalam Peraturan Daerah ini, tetapi Dewan Pemerintah Daerah Istimewa Yogyakarta perlu diberi kekuasaan untuk menunjuk tempat Ibu Kota sementara yang lain, jika faktor-faktor mengenai kepentingan pemerintahan memerlukan tindakan ini, atau hal itu perlu dilakukan dalam keadaan darurat, umpamanya gangguan keamanan, bahaya alam dan sebagainya. Sehingga Dlingo masih beribukota di Imogiri Ska (dlingobantul.desa.id, 2016). 
Desa Dlingo memiliki 10 Dusun (daerah satu level di bawah desa). Sejak 2013 Desa Dlingo menjadi desa percontohan dalam hal tata kelola. Desa Dlingo juga menjadi desa melek Teknologi Informasi (TI) yang ditandai dengan adanya website desa di alamat http://dlingo- bantul.desa.id/ index.php/first.

Dalam kurun waktu sekitar empat tahun (2012-sekarang) desa Dlingo telah mengalami berbagai kemajuan yang dapat dilihat dari struktur organisasi desa yang semkain lengkap, system pelayanan yang cepat dan tepat, serta tingkat kepuasan penduduk pada pemerintah desa yang meningkat. Selain itu, berbagai potensi desa juga terus ditingkatkan, seperti kerajinan, wisata, kuliner, dan budaya. Dari berbagai kemajuan itulah kemudian pemerintah pusat melalui Kementrian Dalam Negeri menjadikan desa Dlingo sebagai tempat studi bagi desa-desa lain di Indonesia dalam hal tata kelola pemerintahan desa.

\section{Hasil dan Pembahasan}

Rumusan dari penelitian ini adalah untuk menggali pemaknaan Lurah Desa Dlingo terhadap konsep pembangunan Desa. Bagi Bapak Bahrun selaku Lurah Dlingo (informan utama), pembangunan desa adalah upaya untuk mencapai suatu visi desa. visi yang beliau usung sendiri adalah "gemah ripah loh jinawi" yang kemudian disingkat dan dijadikan tag line desa ini, yakni "Giri Loji”. Visi yang sejatinya beliau susun sebelum terpilih menjadi Lurah ini terinspirasi dari semboyan yang umum diketahui masyarakat Jawa terkait Nusantara, yakni bermakna bahwa sesungguhnya Desa di Nusantara ini telah dianygerahi oleh sumber daya alam yang berlimpah. Karenanya, penduduknyalah yang harus mampu mengelolanya agar mampu menciptakan kesejahteraan bagi warganya dan berujung pada terwujudnya ketentraman.

Lurah Dlingo mengetahui bahwa desa mereka sebenarnya memiliki potensi yang walaupun dapat dibilang tidak begitu besar, yakni kemahiran warga dalam mengolah kayu menjadi perabotan dan kusen (meja, lemari, tempat tidur, pintu, dsb), kebudayaan desa, dan potensi alam berupa air terjun kecil yang belakangan diberi nama Lepo (singkatan dari Ledok Pokoh). Beliau meyakini secara kuat bahwa sebesar apapun potensi jika tidak dikelola dengan cara yang baik dan benar, maka potensi tersebut tidak akan mendatangkan manfaat. Sementara sekecil apapun potensi yang ada, kita masyarakat mampu memberdayakan, maka akan 
mendatangkan hasil yang tidak terduga kadarnya. Dari dasar ini kemudian Lurah Dlingo berinisiatif untuk berupaya memanfaatkan potensi yang ada tersebut.

Lalu pertanyaan berikutnya adalah, bagaimana visi atau cita-cita ini dapat diraih dengan potensi desa yang tidak bergitu besar di Dlingo?. Pertama yang beliau lakukan adalah memperbaiki tata kelola khususnya pada aspek penegakkan hukum dalam tata pengelolaan keuangan Daerah dan yang kedua adalah peningkatan partisipasi masyarakat dalam mengelola desa yang diawali dengan penyadaran kepada masyarakat desa tentang posisi mereka di dalam pembangunan desa. Bapak Bahrun berpendapat bahwa lengsernya pemimpin Desa Dlingo sebelum beliau yang diiringi dengan dimasukkannya yang bersangkutan ke dalam penjara karena skandal korupsi tidak lepas dari lemahnya upaya dalam taat terhadap aturan yang berlaku, khususnya terkait tata kelola keuangan Desa. secara pribadi beliau berprinsip bahwa dalam setiap aspek kehidupan ada aturan baik yang bersifat konstitusional, alamiah (sunnatullah), maupun ketuhanan. Semua aturan ini beliau yakini bertujuan untuk menjaga keharmonisan apa yang diaturnya, dan esensinya adalah keteraturan dan kebaikan. Karenanya ketika ini tidak dapat dijalankan atau bahkan dilanggar, maka akan mendatangkan kerugian, baik bagi diri sendiri maupun terhadap orang lain, dalam hal ini masyarakat desa. Karena itulah beliau mengawali masa kepemimpinan di Dlingo dengan melakukan identifikasi aturan-aturan terkait pengelolaan desa, yakni Undang-Undang dan aturan adat setempat.

“Jadi kita \{belajar\} dari \{keterpurukan\} kemarin bahwasannya ada \{aturan\} yang \{membingkai desa\} tersebut.... terus belajar tentang perundang-undangan dan \{aturan yang berlaku di desa\} yang \{diatur\} si mbah \{nenek moyang dulu\}. Sehingga, seiring berjalannya waktu mereka (aparatur desa) itu $\{\mathbf{t a h u}\}$ bahwasannya desa itu berjalan diiringi dengan aturan dasar hukum. Sehingga mereka butuh akan informasi aturan itu. Dengan \{adanya aturan\} kita menjadi \{nyaman\}.

Berikutnya, Lurah Dlingo dari hasil survey beliau di Desa menemukan fenomena bahwa kebanyakan warga desa menilai mereka adalah obyek pembangunan dari desa. Menurut Pak Bahrun hal ini berdampak pada sikap dan perilaku warga dimana mereka lebih terlihat pasif terhadap pembangunan desanya sendiri. Bagi Bapak Bahrun ini adalah pola pikir yang salah, karena seharusnya warga desa adalah pewaris desa sehingga seharusnya berada pada garda terdepan dalam 
membangun desa. Menyikapi kondisi inilah Bapak Bahrun sering dalam sambutannya di acara-acara Desa Dlingo menyampaikan gagasannya agar warga menjadi sadar bahwa mereka adalah subyek dan bukan obyek dari pembangunan. Selanjutnya, ketika warga mulai tergerak untuk berpartisipasi dan aktif terlibat dalam pembangunan desa, maka mereka difasilitasi oleh Lurah Dlingo dan segala bentuk karya akan ditunjukkan sehingga warga akan merasa puas, dan keberadaan mereka (eksistensi) terasa benarbenar diakui.

“Kesalahanya

(konsep pengelolaan pembangunan desa sebelumnya-pen) $\}$ adalah terletak pada \{sistem dan personal dari desa\} itu, kan desa sebenarnya lebih tua dari indonesia. Dan bisa disimpulkan desa itu terlahir duluan tapi kenapa kok desa semakin terpuruk dan terpinggirkan. Ternyata \{konsep $\}$ dari orang desa sendiri yang $\{\mathbf{k e l i r u}\}$, sehingga \{harus dirubah\} dari \{dilayani\} menjadi \{melayani\}. Dan \{itu harus kita fahamkan kepada semua...."

Dalam perjalanannya, hambatan dalam dinamika organisasi akan selalu hadir. Tapi dengan semangat berdikari itu, semua permasalahan akan dapat diselesaikan. Menariknya, di luar dari wawancara dengan Lurah, peneliti juga mewawancarai warga untuk melakukan konfirmasi kebenaran wacana yang disampaikan Bapak Lurah. Ternyata apa yang beliau katan benar dan diamini oleh warga. Dan yang lebih menarik adalah, kreativitas warga kini tidak lagi menunggu arahan dari Lurah, tetapi mereka berinisiasi sendiri bahkan tanpa ada jaminan imbalan insentif dari Pemerintah Desa (Pemdes) Dlingo. Hal ini bisa jadi karena masyarakat merasa puas dengan dilibatkannya mereka dalam membangun desa dan ditampilkannya karya-karya mereka ke khalayak ramai (wisatawan) pada pagelaran enam bulanan Dlingo Expo. Selanjutnya sinergi Pemdes dan warga ini berhasil memunculkan potensi ekonomi baru dalam acara Dlingo Expo, dimana banyak wisatawan hadir pada pegalran ini dan ekonomi wargapun mengalami sedikit peningkatan.

"Jadi tahapan \{perubahan good governance , adalah bagaimana kita \{membangun etos kerja $\}$. \{Apabila etos sudah terpatri menjadi karakter\} maka aspek \{kesulitan itu akan hilang; dengan sendirinya."

Apa yang dilakukan Bapak Bahrun ini ternyata nampak membuahkan hasil. Hal ini didapati peneliti dimana warga nampak sangat antusias dalam setiap kegiatan yang berkaitan dengan pembangunan desa, misalnya dalam kegiatan kesenian desa, Lomba Desa, Pengelolaan Lepo, dan banyak kegiatan desa lainnya. Hal ini juga dikonfirmasi oleh 
beberapa kepala Dusun (Kadus) yang salah satunya adalah Bapak Turijan, Kadus Pakis 1.

“...Teman-teman (warga desa) itu selalu \{dilibatkan\} oleh Pak Lurah dalam perencanaan, kegiatan, dan evaluasi mingguan. Dari pedukuhan (pedusunan) adalah tokoh masyarakat, pak RT, tokoh pemuda, kemudian ibu-ibu kader dari pembina paud dan posyandu, karang taruna dusun, kelompok kegiatan masyarakat. Dari situ kumpul \{membicarakan program jangka menengah $\}$ di desa. Kita jadi merasa dihargai Pak Lurah, sehingga semangat untuk berpartisipasi warga itu muncul Mas..."

Selain membangkitkan semangat berdikari (mandiri), Lurah Dlingo juga memberikan pencerahan bahwa pembangunan sejatinya tidak melulu pembangunan fisik desa. Hal ini didasari banyaknya usulan saat partisipasi perencanaan pembangunan desa yang mayoritas berupa pembangunan gedung atau kalau tidak bantuan modal. Bagi Bapak Bahruna pembangunan harus pula meliputi pembangunan manusia di desa Dlingo. Pembangunan manusia ini diimplementasikan dalam bentuk peningkatan aspek-aspek yang berkaitan dengan Indeks Pembangunan Manusia (IPM), meliputi: pertama, pendidikan yang kemudian dijabarkan menjadi; pemahaman keorganisasian masyarakat, pendirian PAUD, Penyelenggaraan lomba-lomba cerdas cermat di banyak Taman Pendidikan Al-Qur'an (TPA) desa, pelatihan pengolahan limbah kayu, budi daya tanaman, kesenian dan kebudayaan dan berbagai bentuk pendidikan lainnya. Kedua terkait aspek kesehatan, dimana diselenggarakan Pos Pelayanan Terpadu (Posyandu), beberapa penyuluhan seperti: pengelolaan kebersihan rumah tangga dan lingkungan, pengelolaan drainase, dan pengelolaan sampah, penyelenggaraan lomba-lomba olah raga, dan lomba kebersihan dusun. Ketiga, pengadaan pelatihan dan pendampingan kewirausahaan untuk peningktan ekonomi.

"di fase awal, \{hambatannya\} adalah \{sudut pandang masyarakat\} yang masih memandang bahwa \{pembangunan itu berupa fisik\}. Jadi untuk pemberdayaan mereka belum ahli dalam membuat rencana bahwa pembangunan itu bukan hanya fisik. Dan biasanya setiap usulan itu berupa bantuan modal. \{Perspektif inilah $\}$ yang $\{$ harus dirubah $\} .. . "$

Informasi yang disampaikan oleh Lurah Dlingo ini konsisten dengan informasi yang diperoleh oleh peneliti dari wawancara dengan Bapak Bravo selaku Bagian Perencanaan Pembangunan Desa. Beliau memaparkan bahwa masyarakat Desa Dlingo yang notabene secara pendidikan mayoritas masih lulusan Sekolah Dasar dan Menengah Pertama belum begitu faham bahwa 
pembangunan tidak hanya secara fisik, tetapi juga manusia (warga) desa itu sendiri.

"masyarakat desa masih mengertinya mbangun itu ya gedung mas. Jadi kalau diarahkan untuk pembangunan manusia, seperti pendidikan dan pelatihan itu mereka dulu itu kurang tertarik. Tapi dengan pendekatan dan penyuluhan dari tim Desa secara terus-menerus dan dengan cara yang santun, masyarakat mulai menerima bahwa pembangunan manusia itu juga penting. Hal itu dapat dilihat dari usulan yang pada periode terakhir tidak lagi didominasi minta pendirian bangunan atau gedung."

Konsep pembangunana Giri Loji yang diusung oleh Lurah Dlingo ini juga bersumber pada keyakinan beliau sebagai seorang yang beragama dimana beliau memahami bahwa perubahan menuju pada perbaikan tidak dating dengan sendirinya. Manusia harus berusaha untuk merubah keadaan dengan hasil akhir tetap berharap pada Yang Maha Kuasa. Hal inilah yang kemudian menggiring beliau untuk mengajak warga untuk terus berkarya agar kebaikan dan kesuksesan desa dapat diraih. Dengan demikian dapat dikatakan bahwa konsep pembangunan desa yang diusung Lurah Dlingo tidak hanya yang ditopang oleh konsep manajemen serta tata kelola yang apik, tetapi juga harus dibarengi dengan penghadiran peran Tuhan Yang Maha Esa agar kinerja desa yang ditargetkan dapat tercapai.

"\{ghirah\} semangat kami, \{prinsipnya\} adalah bahwasannya \{Tuhan tidak merubah nasib suatu kaum, kecuali kaum tersebut yang merubahnya sendiri\}. Dan \{prinsip lain\} adalah \{Tuhan sesuai dengan prasangka hambanya $\}$. Maka, \{kita harus bangkit karena kita pernah hancur\}, dan \{kita harus berubah untuk menjadi ahlinya dan lalu meraih sukses\}."

Terakhir, makna pembangunan bagi Pemdes Dlingo adalah sebuah kewajiban yang kemudian menjadi komitmen bagi pihak yang diamanahi. Karena itu, amanah ini harus dijalani dengan berani. Selain itu, dalam pembangunan, beliau menilai, banyak pihak harus trlibat, terlebih untuk pemerintah desa. Beliau menyadari bahwa Sumber Daya Desa masih banyak keterbatasan. Banyak aspek yang tidak difahami dengan baik oleh Pemdes. Karenanya sinergi dengan berbagai pihak harus dijalankan, ungkap beliau. Ini pula yang kemudian menggiring Dlingo untuk membangun sinergi dengan Pemkap Bantul, beberapa Universitas di Yogyakarta, dan membentuk Forum Lurah Desa (FDL) se Kabupaten Bantul. Kerjasama ini diinisiasi oleh kesadaran Lurah Dlingo dan bukan dari tuntutan Undang-Undang. Beliau meyakini bahwa dengan bekerjasama dan bergotong royong dalam pembangunan, maka banyak hal yang 
dapat dipelajari, dan masalah berat akan terasa ringan jika dihadapi bersama. Banyak hal yang beliau jadikan permisalan. Diantaranya, perumusan strategi, Pemdes yang tadinya tidak faham menjadi mengerti berkat pendampingan dari Pihak Kabupaten Bantul dan Universitas. Terkait pembangunan potensi desa, beliau banyak belajar dari diskusi yang diadakan di FDL.

"Itu berasal dari \{komitmen\} pemerintahan desa. Jadi keinginan untuk \{berubah\}. Dan yang \{paling penting\} adalah \{berubahnya pemerintahan desa dengan berani\}."

"Kita punya forum lurah desa atau FLD se-Kabupaten Bantul untuk wadah \{berdiskusi\}. Jadi kita sudah seperti saudara di kabupaten Bantul untuk lurah-lurah itu. FDL ini kita bentuk karena \{semangat berkemajuan secara berjama'ah\}... selain dengan FDL, untuk menopang pembanguan desa, \{sinergi\} juga kita bangun dengan banyak pihak, pemkab, pengawas, perguruan tinggi. ini untuk sarana \{belajar\} kita (Pemdes) disamping silaturrahim. Prinsipnya $\}$ adalah gotong royong\}."

\section{KESIMPULAN, IMPLIKASI DAN KETERBATASAN PENELITIAN}

Dari hasil analisis atas wawancara mendalam dengan Lurah desa Dlingo dan disertai konfirmasi dari beberapa informan, peneliti dapat menyimpulkan bahwa makna pembangunan desa berbasis Giri Loji (merupakan singkatan dari Gemah Ripah Loh Jinawi Toto Tentrem Kerto
Raharjo) yang digagas oleh Lurah Desa Dlingo bermakna sebuah desa harus memiliki visi untuk menjadi desa yang memiliki dan mampu memberdayakan kekayaan alam yang melimpah dengan tujuan menciptakan keadaan yang tentram secara lahir dan bathin. Bagi orang jawa lama slogan ini sangat familiar sehingga bukan hal yang baru bagi kebanyakan warga Dlingo. Namun, bagi Lurah Desa Dlingo slogan tersebut menjadi inspirasi untuk berkembang yang mana cita-cita ini akan sulit tercapai ketika pemaknaan akan pembangunan desa tidak ditafsirkan dengan baik.

Bagi beliau pembangunan berbasis pada konsep manajemen dan tata kelola adalah pembangunan yang berbasis pada ketaatan pada aturan, baik yang berlaku dalam konstitusi (Undang-Undang), maupun aturan sebagai seorang hamba tuhan dan bagian dari alam. Dengannya, beliau yakin keteraturan akan diperoleh dan ketentraman itu akan diraih. Selain itu, konsep utama tata kelola atau governance adalah memanusiakan manusia, dengan membangkitkan kesadaran mereka (warga desa) bahwa mereka adalah pewaris Desa. Perubahan ke arah yang lebih baik tidak akan terjadi jika mereka berdiam diri, yakni memposisikan diri sebagai obyek dan bukan subyek dari 
pembangunan. Dengan hadirnya kesadaran membangun, maka semangat warga desa akan lahir dengan sendirinya dan programprogram produktif akan muncul dari warga dengan didasari kesadaran, kreatifitas, dan inovasi yang dipenuhi keikhlasan. Inilah yang beliau nilai sebagai hakikat partisipasi masyarakat dalam sebagai salah satu prinsip good governance. Selain itu, bagi beliau pembangunan harus dibarengi dengan ketaatan pada Tuhan Yang Maha Esa. Sebagai hamba manusia tetap harus berusaha untuk meraih kesuksesan. Akan tetapi, seorang manusia harus tetap menghadirkan Tuhan dalam segala upaya mereka, karena apapun yang dilakukan manusia hasil akhir tetap ditentukan oleh kehendak tuhan. Terakhir, governance yang baik adalah adanya komitmen berani dari seluruh elemen desa untuk berubah dan dijalani dengan semangat gotong royong, silaturahim dan tolong menolong. Hal ini dapat dilihat dari dibentuknya sinergi-sinergi Desa Dlingo dengan berbagai pihak. Beliau meyakini bahwa kesatuan akan melahirkan suatu keberhasilan kelompok yang kuat dibandingkan dilakukan secara sendiri-sendiri.

\section{REFERENSI}

Bastian, I. 2006. Akuntansi Sektor Publik. Jakarta: Erlangga.

Brinkerhoff, D. W., dan J. M. Brinkerhoff. 2011. Publicprivate partnerships: Perspectives on purposes, publicness, and good governance. Public Administration and Development 31 (1), 2-14.

Creswell, J. W. 2012. Research Design: Qualitative, Quantitative and Mixed Methods Approaches. California: Sage Publication.

Handoko, T. H. 2015. Dasar-dasar manajemen produksi dan operasi. Yogyakarta: BPFE.

Jones, R., dan M. Pendlebury. 2010. Public Sector Accounting. England: Prentice Hall.

Kamayanti, A. 2016. Metodologi Penelitian Kualitatif Akuntansi: Pengantar Religiositas Keilmuan. Jakarta: Yayasan Rumah Peneleh.

Lestari, A. K. D., A. T. Atmadja, I. M. P. ADIPUTRA, dan M. Si. 2014. Membedah Akuntabilitas Praktik Pengelolaan Keuangan Desa Pakraman Kubutambahan, Kecamatan Kubutambahan, Kabupaten Buleleng, Provinsi Bali (Sebuah Studi Interpretif pada Organisasi Publik Non Pemerintahan). JIMAT (Jurnal Ilmiah Mahasiswa Akuntansi S1) 2 (1).

Mahsun, M., F. Sulistyowati, dan H. A. Purwanugraha. 2007. Akuntansi Sektor Publik. Edisi Kedua. BPFE: Yogyakarta. 
Mamulati, I., I. Triyuwono, dan A. D. Mulawarman. 2016.

Fenomenologi Sumber Daya Manusia Sebagai Aset Intelektual Dalam Amal Usaha Muhammadiyah. Jurnal Akuntansi dan Investasi 17 (1), 93-103.

Munti, F., dan H. Fahlevi. 2017. Determinan Kinerja Pengelolaan Keuangan Desa: Studi pada Kecamatan Gandapura Kabupaten Bireuen Aceh. Jurnal Akuntansi dan Investasi 18 (2), 172-182.

Republik Indonesia. 2014a. UndangUndang Nomor 6 Tahun 2014 Tentang Desa.

- 2014b. Undang-Undang Republik Indonesia Nomor 23 Tahun $2014 \quad$ Tentang Pemerintahan Daerah.

Subroto, A. 2009. Akuntabilitas Pengelolaan Dana Desa. Universitas Diponegoro. Semarang.

Suryaningrum, F. 2016. Analisis Pengelolaan Dana Desa 2015 (Studi Kasus Di Desa Arjosari, Kecamatan Arjosari, Kabupaten Pacitan), University of Muhammadiyah Malang.

Ulum, I., dan H. Sofyani. 2016. Akuntansi (Sektor) Publik. Yogyakarta: Aditya Media Publishing.

Wida, S. A., D. Supatmoko, dan T. Kurrohman. 2017. Akuntabilitas Pengelolaan Alokasi Dana Desa (ADD) di Desa-Desa Kecamatan Rogojampi Kabupaten Banyuwangi. e-Journal Ekonomi Bisnis dan Akuntansi 4 (2), 148-152. 